\title{
Graduate Tracer Study Design System Using Web-Based GPS (Case Study Universitas Advent Indonesia)
}

\author{
Gastan Gaoudio Thomas ${ }^{1}$, Elmor Wagiu ${ }^{2}$ \\ Faculty of Information Technology, Universitas Advent Indonesia \\ Elmor@unai.edu
}

\begin{abstract}
Graduates is one of the important support in the development of a university. Graduates have a role to assist universities in developing the university into the community through collaboration in academic terms. Since the establishment of the Universitas Advent Indonesia (UNAI) to date has resulted in 12.608 qualified graduates, but the problems that exist today data on students graduated from UNAI difficult to find because UNAI not have a special service for containing information about the data the continuation of a career every graduate that will be created as a relationship that can support the advancement of the quality of graduates at the Universitas Advent Indonesia.System graduate tracer study using GPS-based site aims to make it easy for university graduates to know the position, length of time required to get a job and know the activities that diinsiasi graduates. The system is designed graduate tracer study using a web-based system. This site can be used by the Study program or the University authorities and also the graduates to see reports on graduates. The data collection is done by filling the registration form of the tracer system. The system is built using the waterfall method where the method of initiation systems development, design, implementation, testing, and maintenance. Laravel framework for building websites and using the Global Positioning System (GPS), which serves as a locator graduates. The end result of this research is the system can track and know the position of graduates as well as get information required of the graduates who have recently graduated or long pass. Can know how long it takes graduates to get a job after graduation. And also be able to know the activities that will be initiated by graduates on campus UNAI. It is expected that the future can be developed to add features that are useful scholarship to help students who are still studying, and add graphics on the information of graduates in finding employment.
\end{abstract}

Keywords: Tracer Study, GPS, laravel, Waterfall.

\section{INTRODUCTION}

One of the factors supporting a university quality can be seen through graduate or graduates.

Due to the graduates is a product of an educational institution that directly interact with the people in the working world. Graduates also have an important role in developing educational institutions, due to the graduate can become an example in the public how the quality of the graduates of educational institutions. By knowing how their story in the community, the 
university will get the information, feedback and motivation to further develop the performance, so as to maximize future graduates to be able to adapt to the needs and demands of society in the future. Therefore, the information from graduates to support the advancement of education in the university.

Since established from 1949 until now, the Universitas Advent Indonesia (UNAI) has graduated 12.608 people who have been instrumental in people with different professions and positions are scattered to different places and regions. However, information about these graduates still have not been recorded due to the lack of services that can accommodate such information. Tracer study can facilitate information to the university like to know how long it takes graduates to get a job after graduation, can determine the activities to be initiated by graduates on campus UNAI, and can also be an opportunity to work together as a job, funding, and cooperation in terms of information.

For which the author wants to create a " graduate tracer study design system using web-based gps Universitas Advent Indonesia" that can later be used as a medium that can be used by graduates, faculty, and the rector to communicate and exchange information. Besides, the system can also be used to help the college graduates in managing the data needed to help advance the future campus. Created using a web-based framework laravel and database system MySQL. Laravel is a PHP-based web application framework that is open source, using the concept of MVC: Model View Controller. To the authors make the formulation of the problem, how to design and create websites graduate information systems in order to benefit as a forum to get information and make applications tracer.

\section{LITERATURE REVIEW}

\section{Laravel}

From opinion (B, Safi'ie, and WA, 2016) Laravel is a framework of openPHP is a free web-based source made by Taylor Otwell and is intended for web application development follows the model-viewcontroller (MVC) architecture or patterns. Some of the features of laravel is the development of system modules that can be has, introducing a different way to access the relational database, the utility that assists in application deployment and maintenance easy.

\section{Waterfall}

According to (Pressman, 2015, P.42) The waterfall model, sometimes called the classic life cycle, indicating the approach of a systematic, sequential to software development that begins with the customer specifies the desired requirements and progresses through planning, modeling, construction, and deployment, culminating in ongoing support of software that has been completed 
Stages of Waterfall Model reflects the main points of development activity: Communication (Requirements gathering) Services provided by the system, the system limits, and goal set after consultation with users of the system. All are defined in detail and made as a specification of the system.

\section{Tracer Study}

Based on the opinion (Khair, Astuti, and Khairina, 2016) quoting from (Vermeulen, 2006) Tracer graduates or it could be called tracer studies or graduate studies, in general explore the unique perspective of graduates higher education regarding the contribution of education to their lives after graduation. And according to Romi Mardela (Padang, 2015), tracer study is a way to keep track of graduates, graduates know the condition, how they work, their competence. Tracer study is also evaluating the results of education, because it examines the transition between university education with the professional world. How far they get to an education and career contributions.

\section{Graduate}

Based on the opinion (Khair, Astuti, and Khairina, 2016)quoting from Indonesian Dictionary third edition (2005), said the graduates have the sense that people who have attended or graduated from a high school or college. Graduates is the plural form of the word alumnus. Graduates show a lot of people while alumnus is singular that shows only one person. In other words, graduates are graduate or graduate group.

\section{METHODS}

\section{Use Case Diagram}

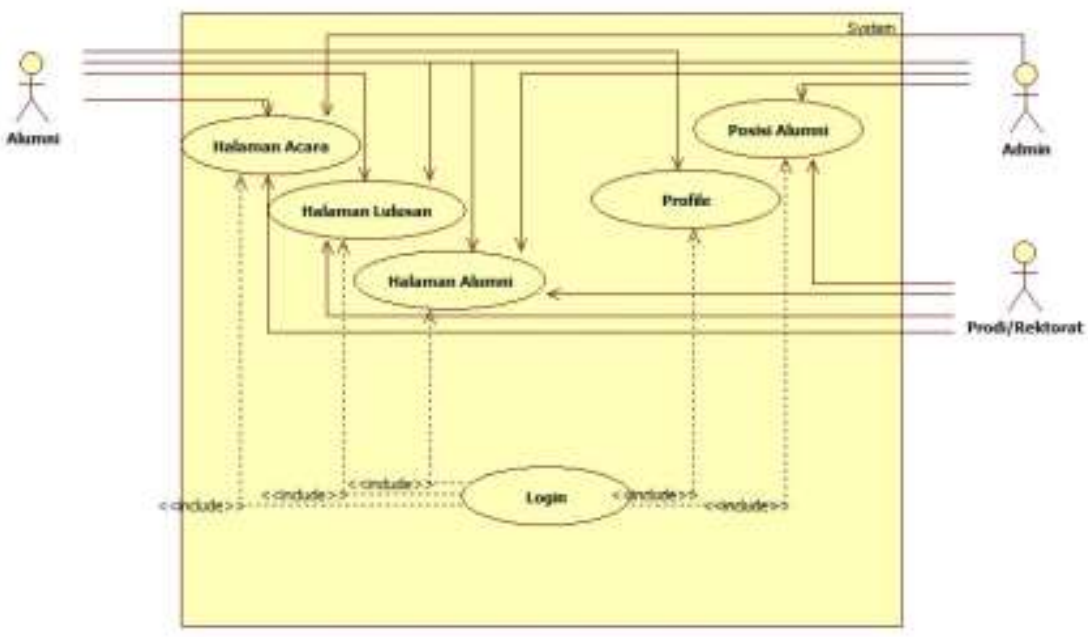

Figure 1. Use Case Diagram

Based on the existing use case diagram This website has three users including: admin as the manager of the system, graduates as the core of the content of this website is created. Study program / rector as a forum to find out what activities are to be carried out by graduates. Admin has access to add, edit and also viewed from the event function, graduate, graduate and study program position 
to have access to add or edit graduates and see the position of every graduate who filled out the form. Graduates have access to the page to register, events, graduate, graduates, and also profile.

\section{Activity Diagram}

\section{Diagram Activity Login}

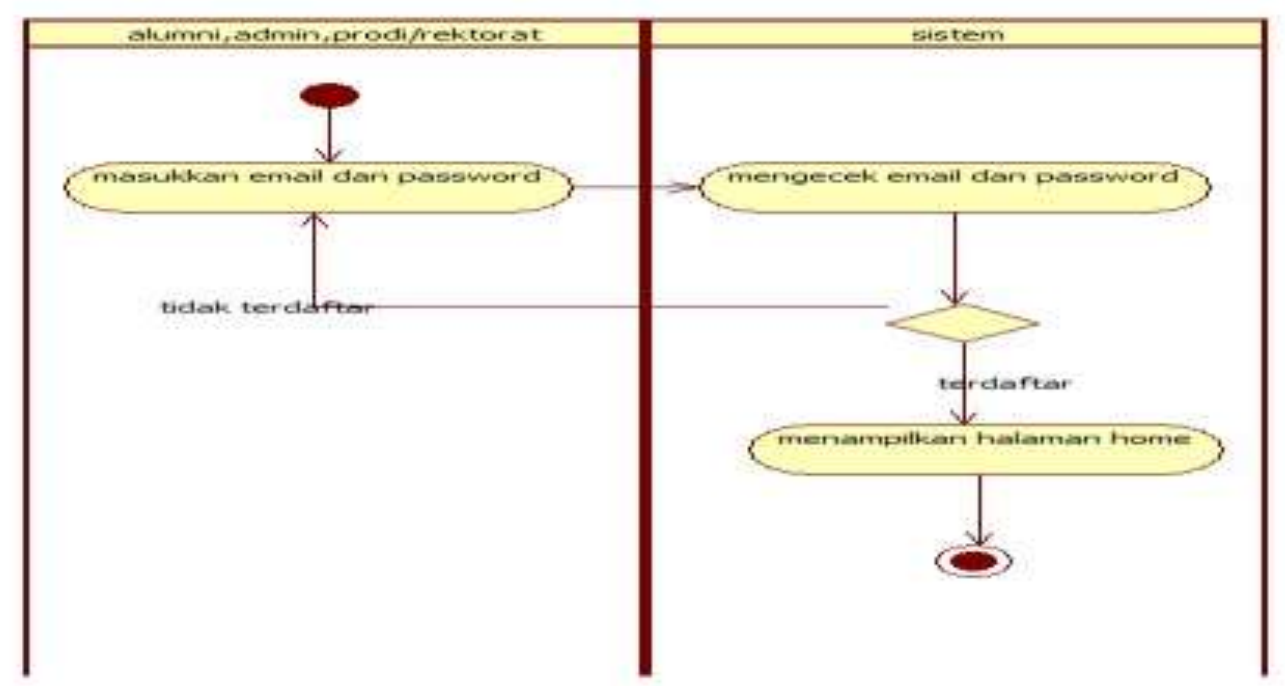

Figure 2 Activity Diagram Login

This diagram explains the graduate login process, admin, study program / rector must enter your email and password and the system checks whether an email is already registered or not when it is then it will go to the home page.

\section{Events page}

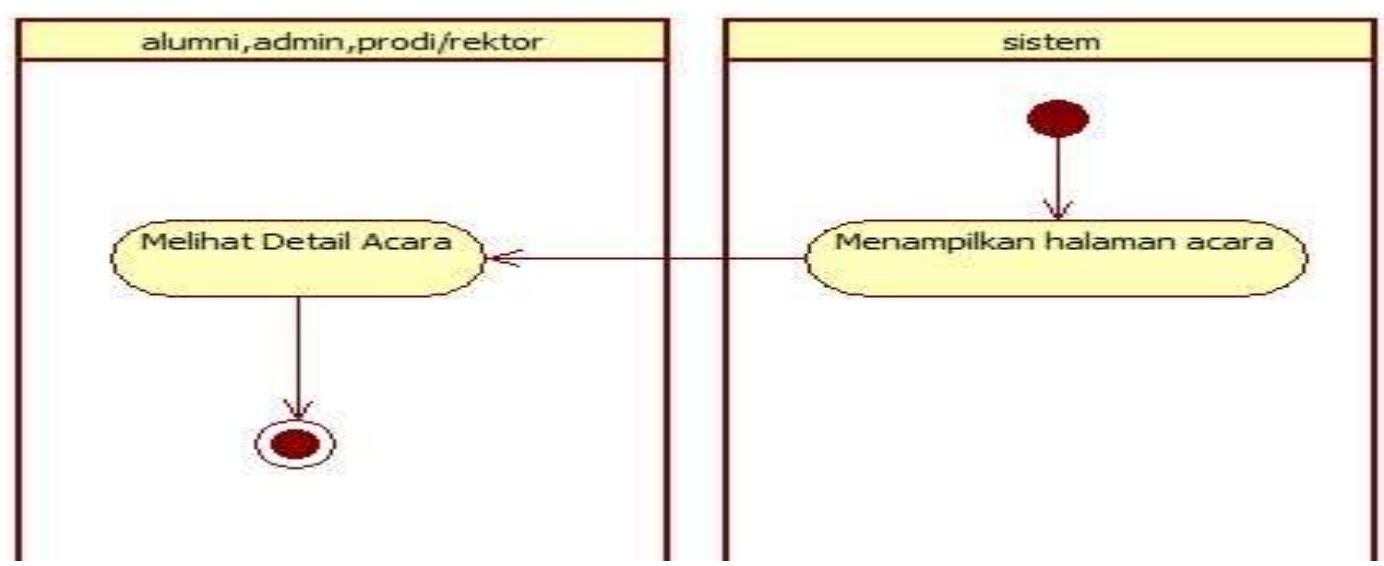

Figure 3. Activity Diagram Events page

This diagram describes the process of events page on this page graduates, admin, study program / rector can see graduates who had just graduated from Universitas Advent Indonesia.

\section{New Graduates page}




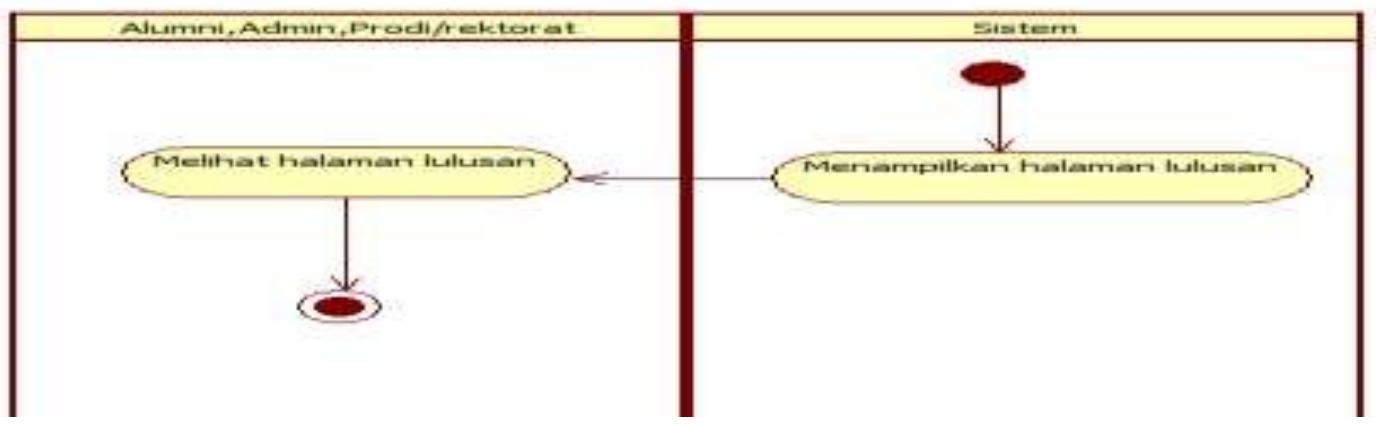

Figure 4. Activity Diagram Page New Graduates

This diagram describes the process of pages graduate graduates on this page, the admin, study program / rector can see graduates who had just graduated from Universitas Advent Indonesia.

\section{Graduates page}

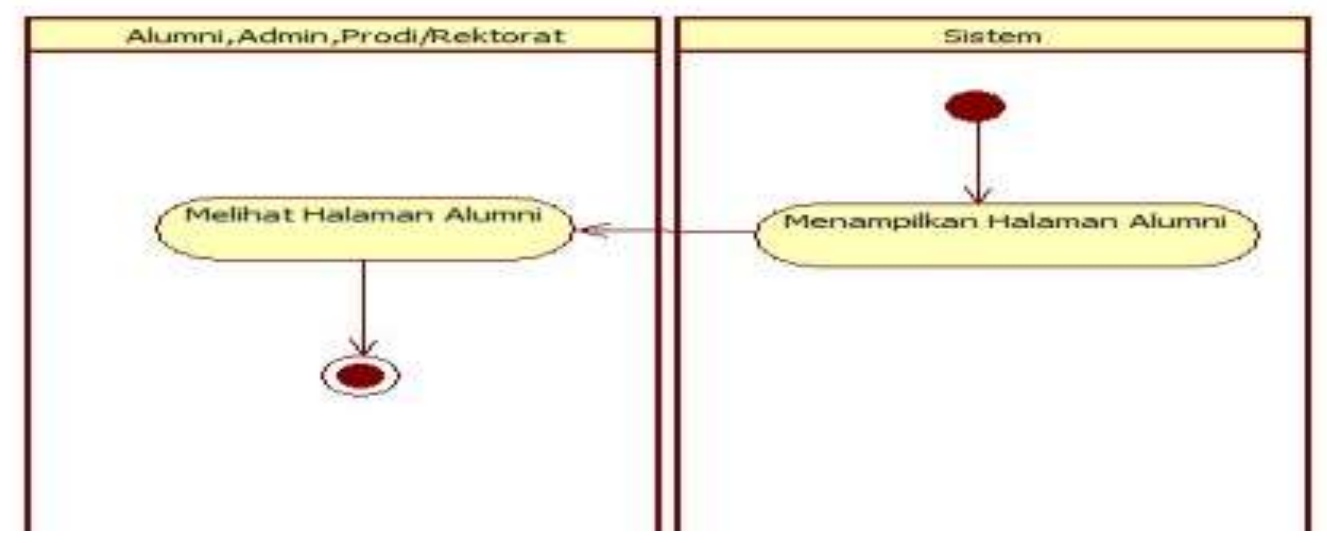

Figure 5. Activity Diagram Page Graduates

This diagram describes the process of pages graduate graduates on this page, the admin, study program / rector can see graduates who have filled in the form of the Universitas Advent Indonesia.

\section{Profile}

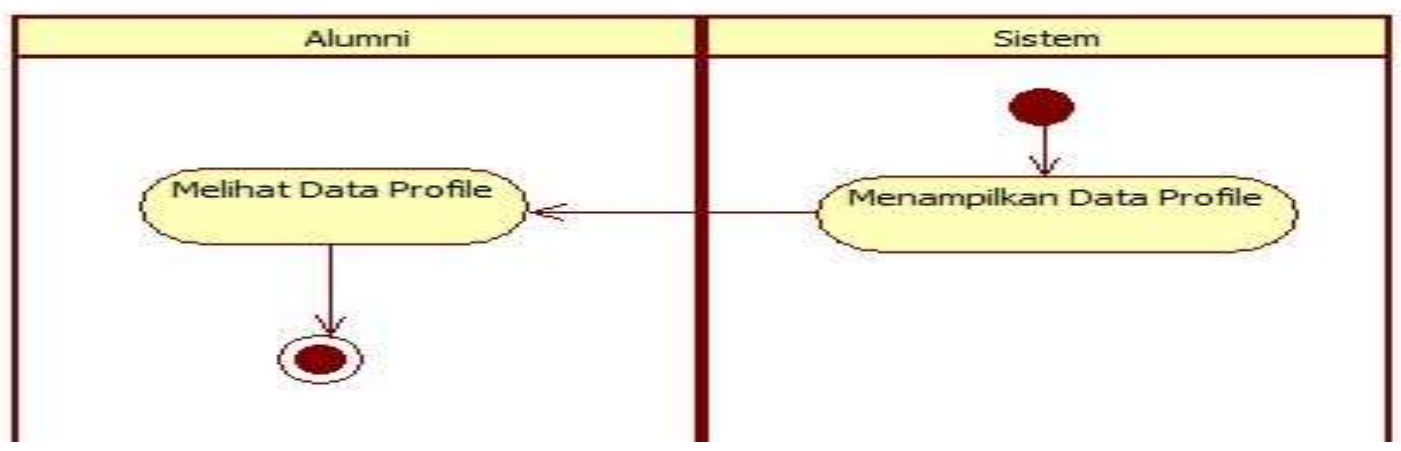

Figure 6. Activity Diagram Profile page

This diagram describes the process of the profile page on this page graduates can view / edit form of a profile that had the content data themselves graduates. 


\section{Graduates Position page}

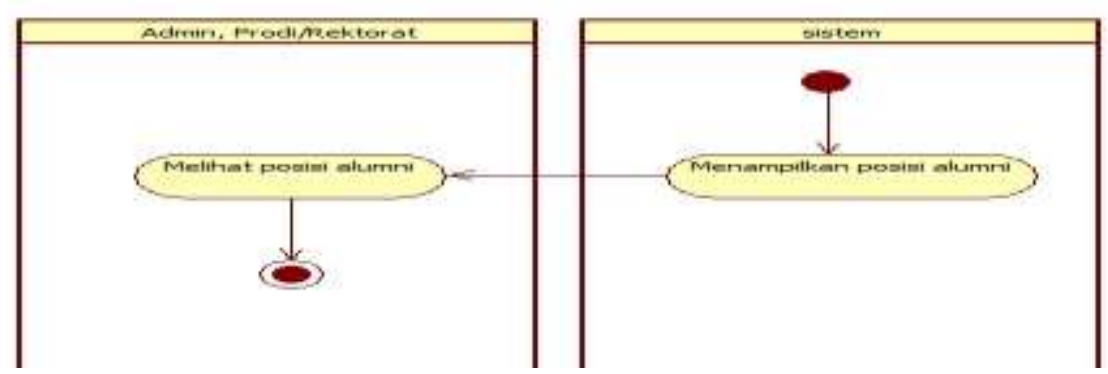

Figure 7. Activity Diagram Page Position Graduates

This diagram describes the process of events page on this page graduates, admin, study program / rector can see graduates who had just graduated from Universitas Advent Indonesia.

\section{Sequence Diagram}

\section{Login}

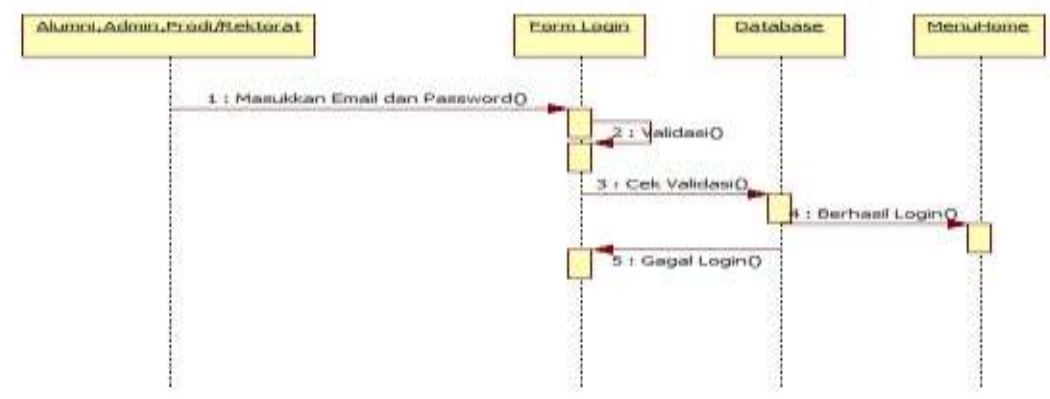

Figure 8. Sequence Diagram Login

In this diagram will explain the login process of graduates, administrators, and study program / rector which will fill in email and password in the login form will be validated in the database when it is appropriate it will go to page home, but if it does not fit then it will re-view the first login.

\section{Events page}

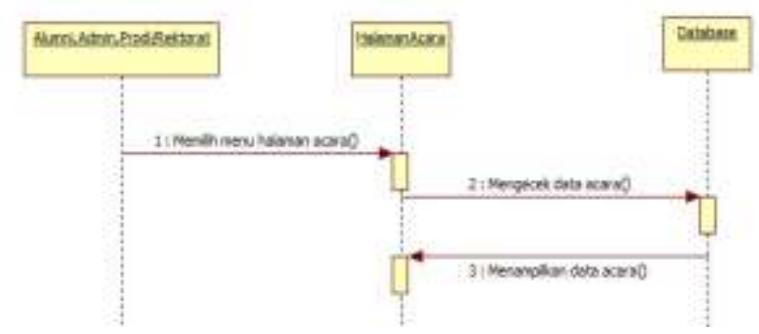

Figure 9. Sequence Diagra, Events page 
In this diagram will show the process of graduates, administrators, and study program / rector during the opening page of the event, at which time the database is opened the event page will check for news of what is available and then will present it to the main page of the event.

\section{New Graduates page}

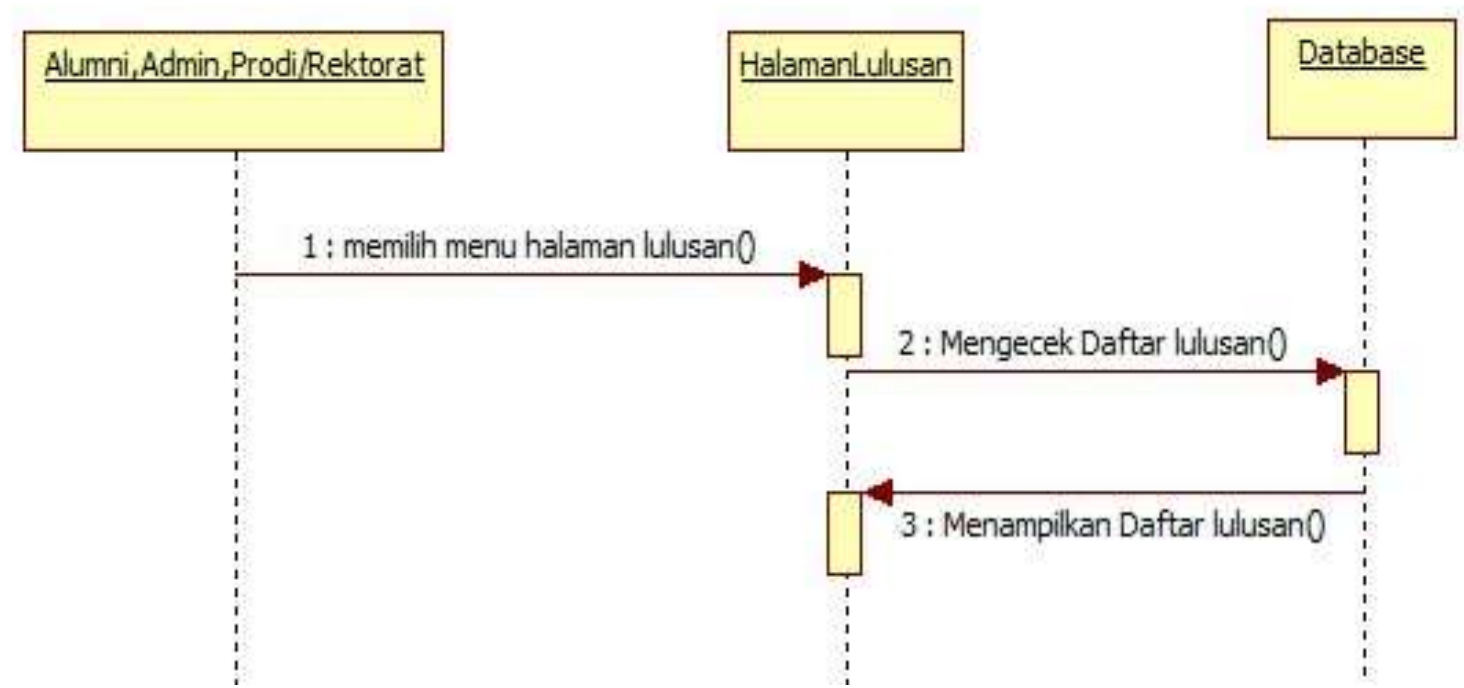

Sequence Diagram Figure 10. New Graduates page

In this diagram will show the process of graduates, administrators, and study program / rector when opening a page of graduates, at which time the page is opened graduates then will check the database graduates who have entered the data and will present it to the main page of graduates.

\section{Graduates page}

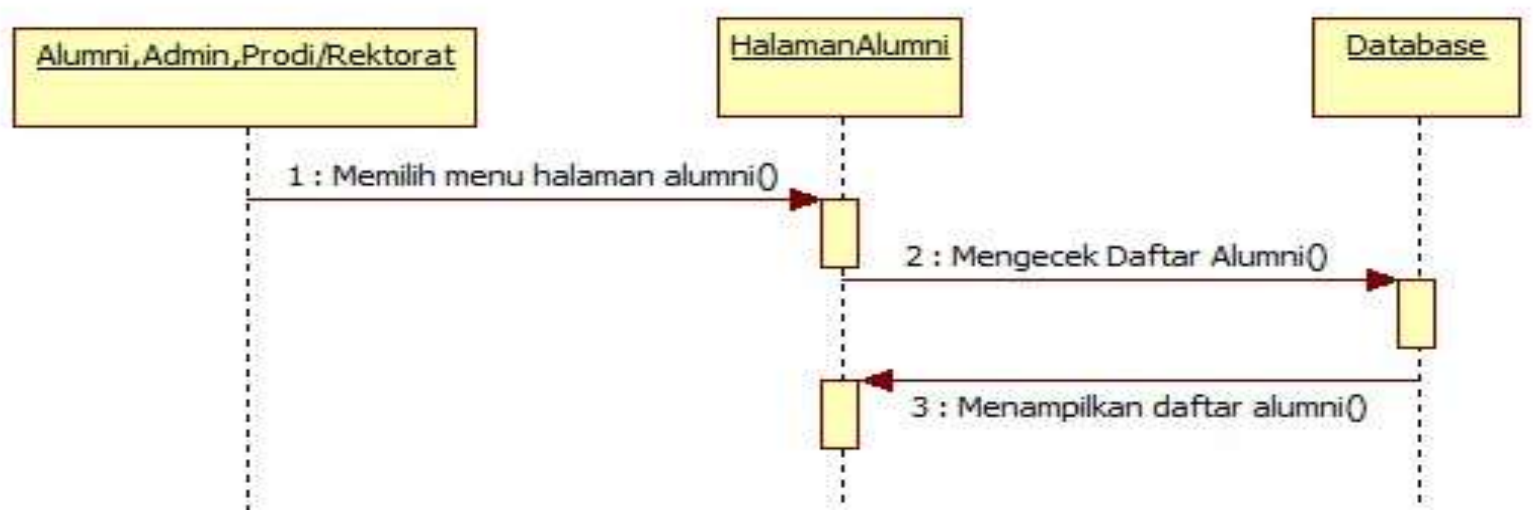

Figure 11. Sequence Diagram Alumi page

In this diagram will show the process of graduates, administrators, and study program / rector when opening a page of graduates, at which time the page is opened graduates then will check the database of graduates who filled out the data in the form of graduates and will present it to the main page of graduates 


\section{Profile}

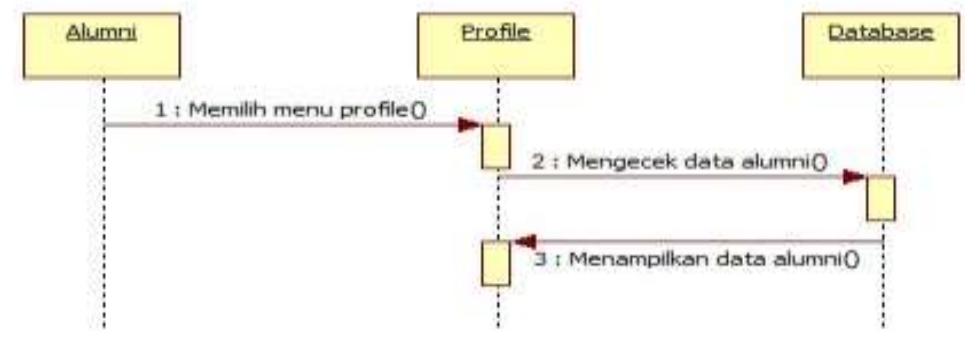

Figure 12. Sequence Diagram Profile

In this diagram will explain the process whereby the profile of graduates graduates graduates will see the data after the data to fill in the registration form will be checked in the database and display it on the profile page.

\section{Position Graduates}

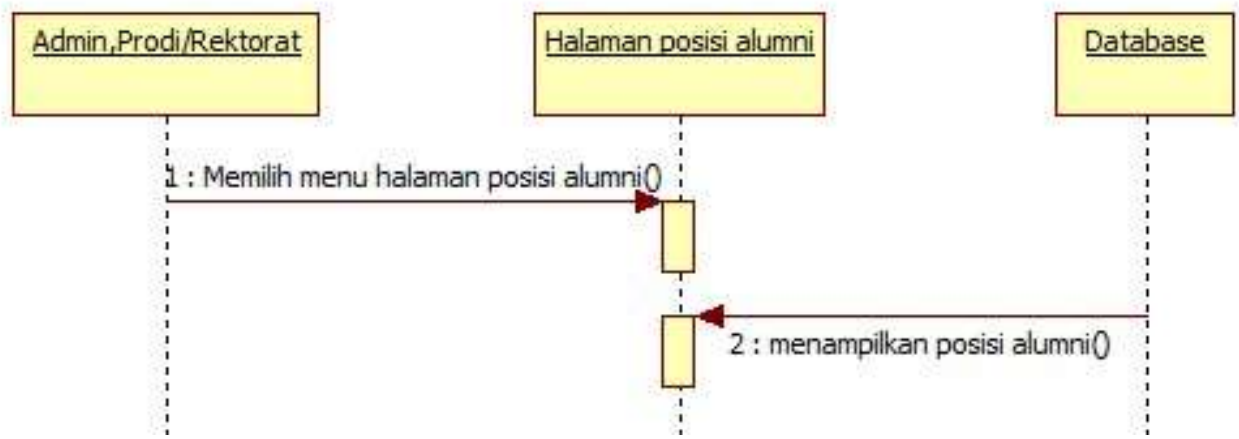

Figure 13. Sequence Position Diagam Graduates

In this diagram will explain the position of graduate page where graduates have filled in the data in the registration form will be checked in the database and display it on the page position of graduates.

\section{Class Diagram}

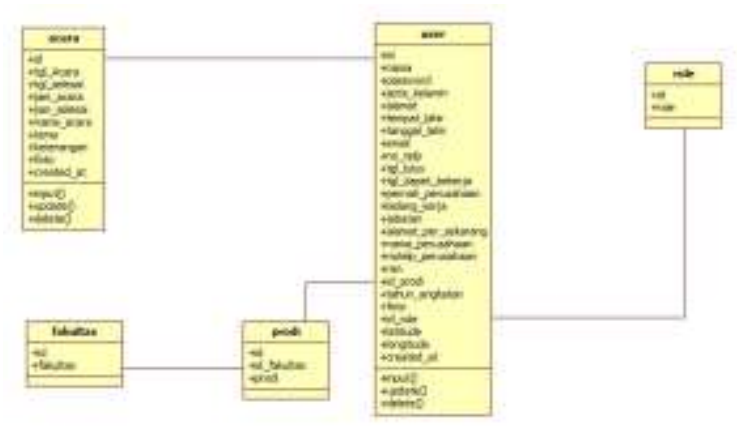

Figure 14. Class Diagram 


\section{Deployment Diagram}

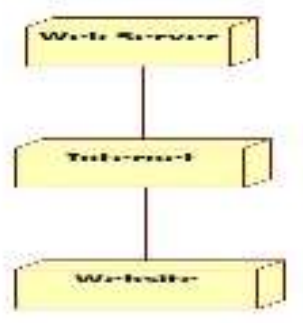

\section{Figure 15. Deployment Diagram}

\section{RESULTS}

Display User Login

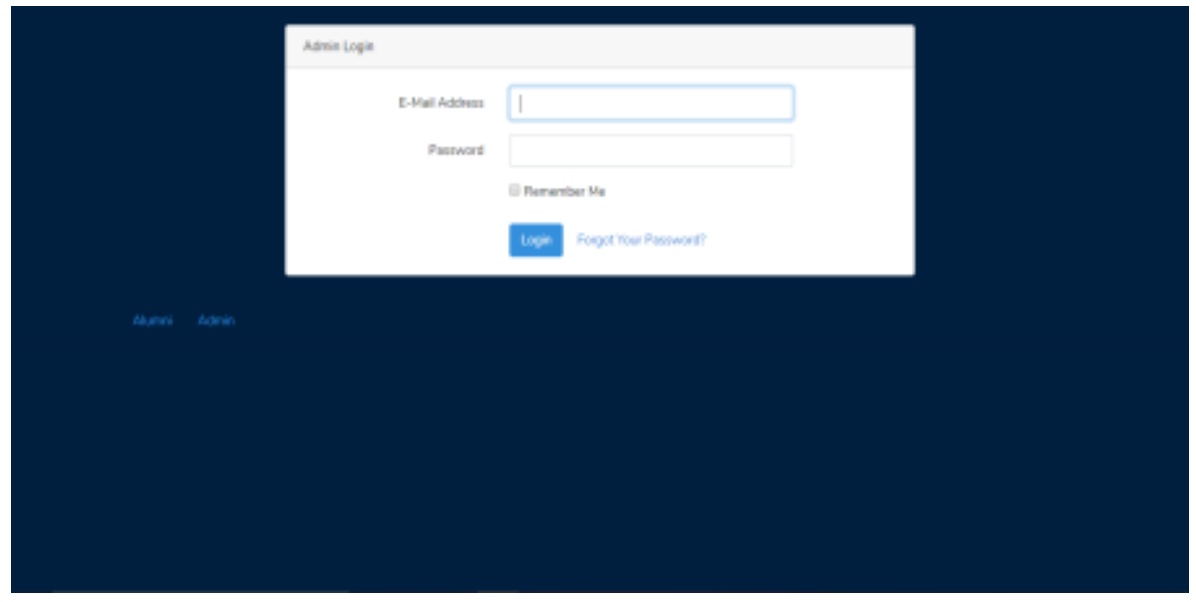

Figure 16. Display User Login

In view user login (Graduates, Admin, Rector / Study program) will enter the email and password that have been registered.

\section{Home Page Views}

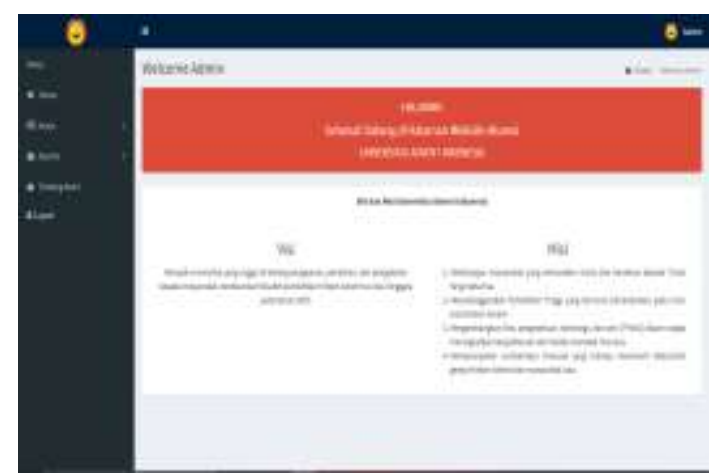

Figure 17. Display Home

1834 
After the user login (Graduates, Admin, Study program / Rector) will enter the main kehalaman of tracer system.

\section{Display Events}
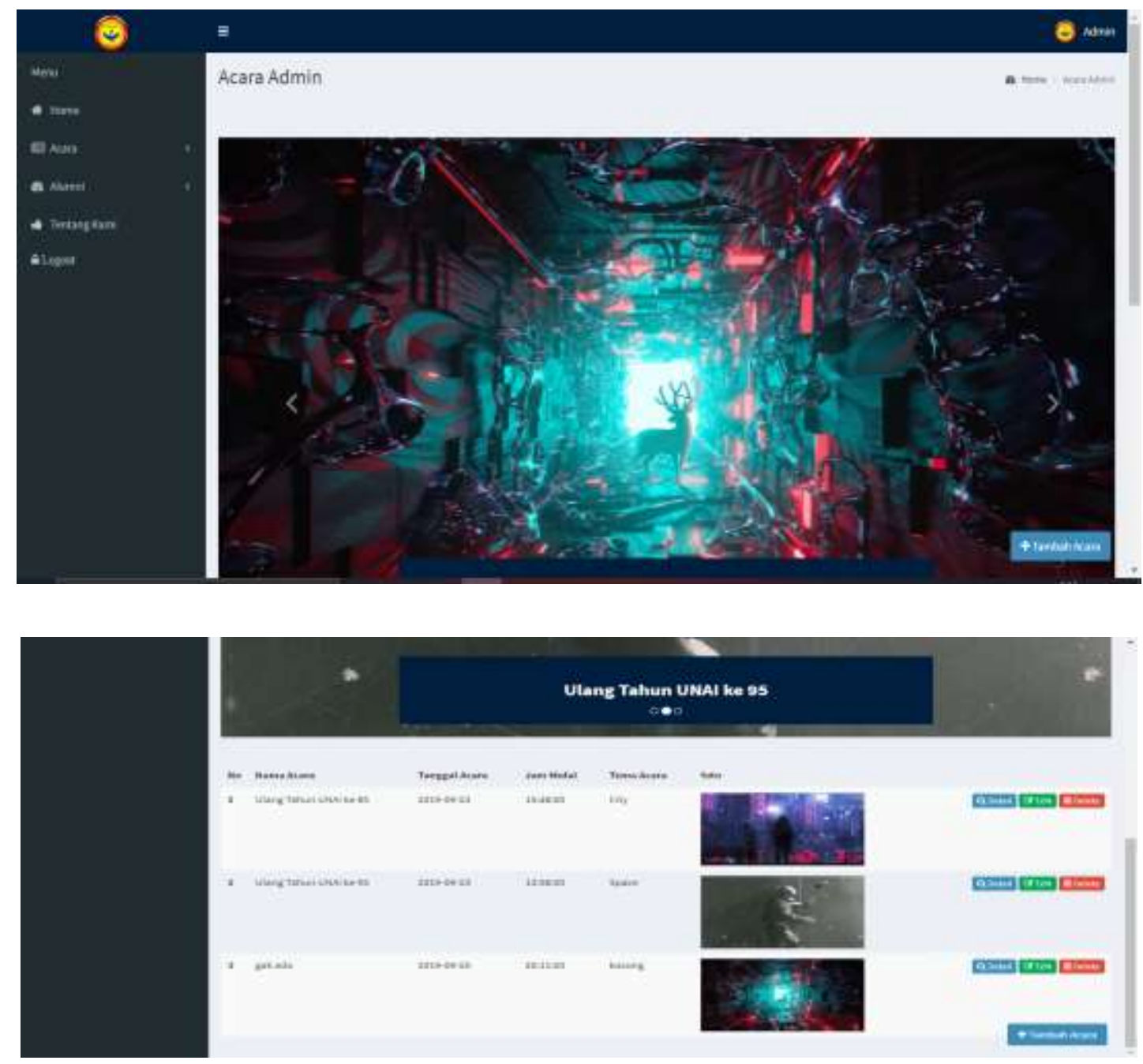

Figure 18. Event page

On the event page manual (Graduates, Admin, Rector / Study program), will see events that took place on the campus of UNAI future. Users (Graduates, Admin, Rektrorat / Study program) can see the event details to find out the full event that took place. User (Admin) can access the add events, edit events, and do delete the event. 


\section{Display Add Event}

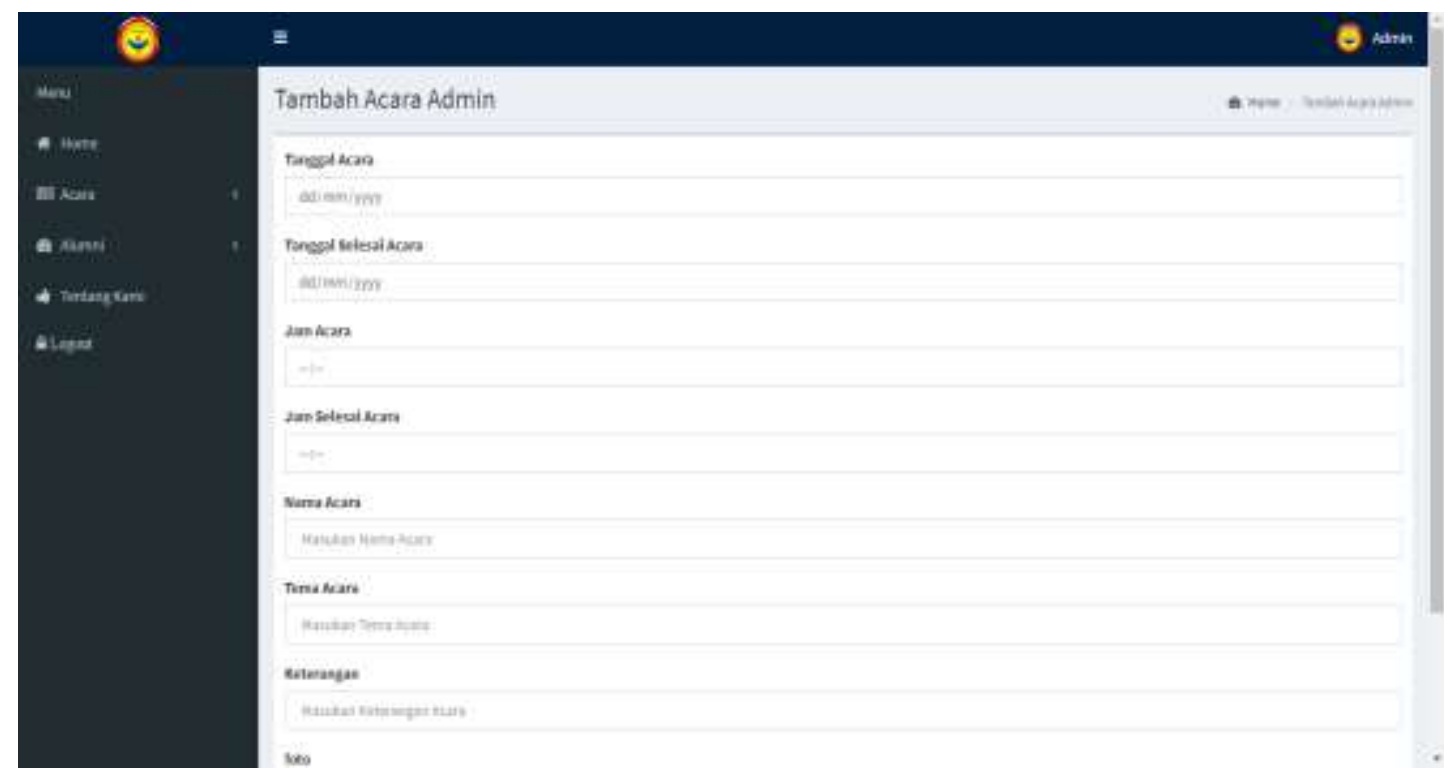

Figure 19. Display Add Event

On Page Add events, only admin dapet do add events, in the admin added this event will fill the data necessary for the execution of the event at the university.

\section{Detail View Events}

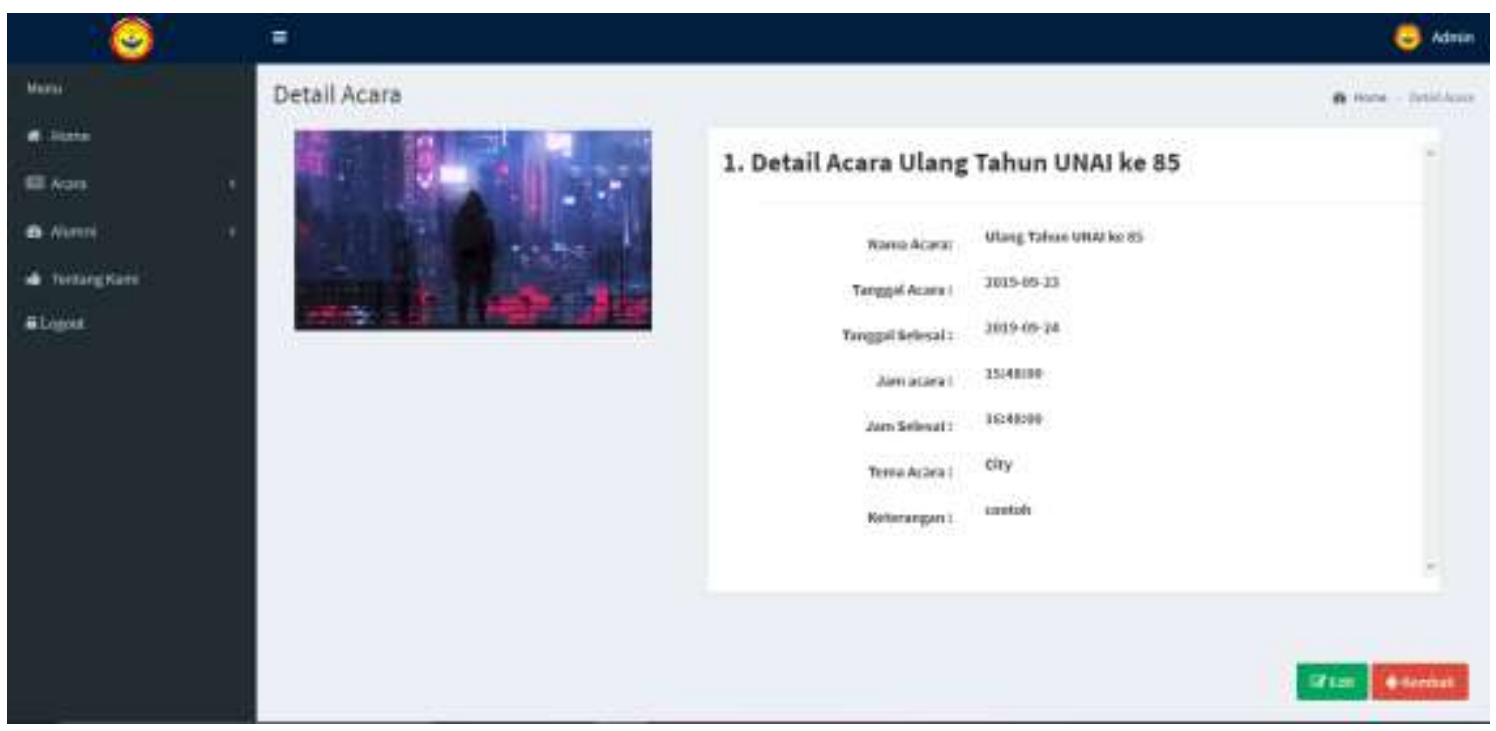

Figure 20. View Event Details

In the Detail View user event (Graduates, Admin, Study program / Rector) can view the contents of the whole event will take place at the university. Admin can edit if there is to be changed 


\section{Display List of Graduates}

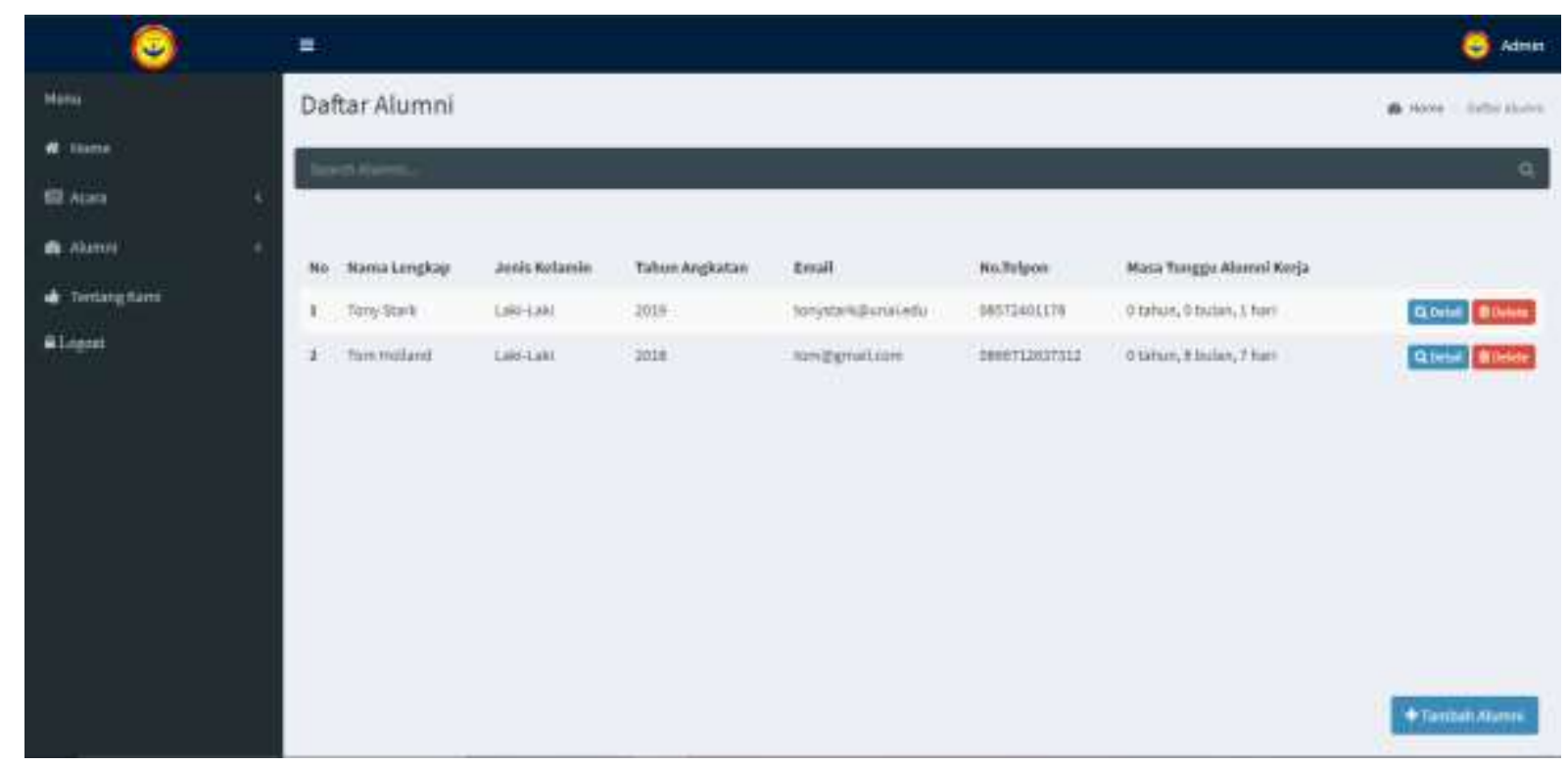

Figure 21. List Graduates

On page Display List Graduates, Users (Graduates, Admin, Study program / Rector) can see the list of students or students who already graduated from Universitas Advent Indonesia. Which will add / delete data is a user graduates (Admin / Study program).

\section{Display Add Graduates}

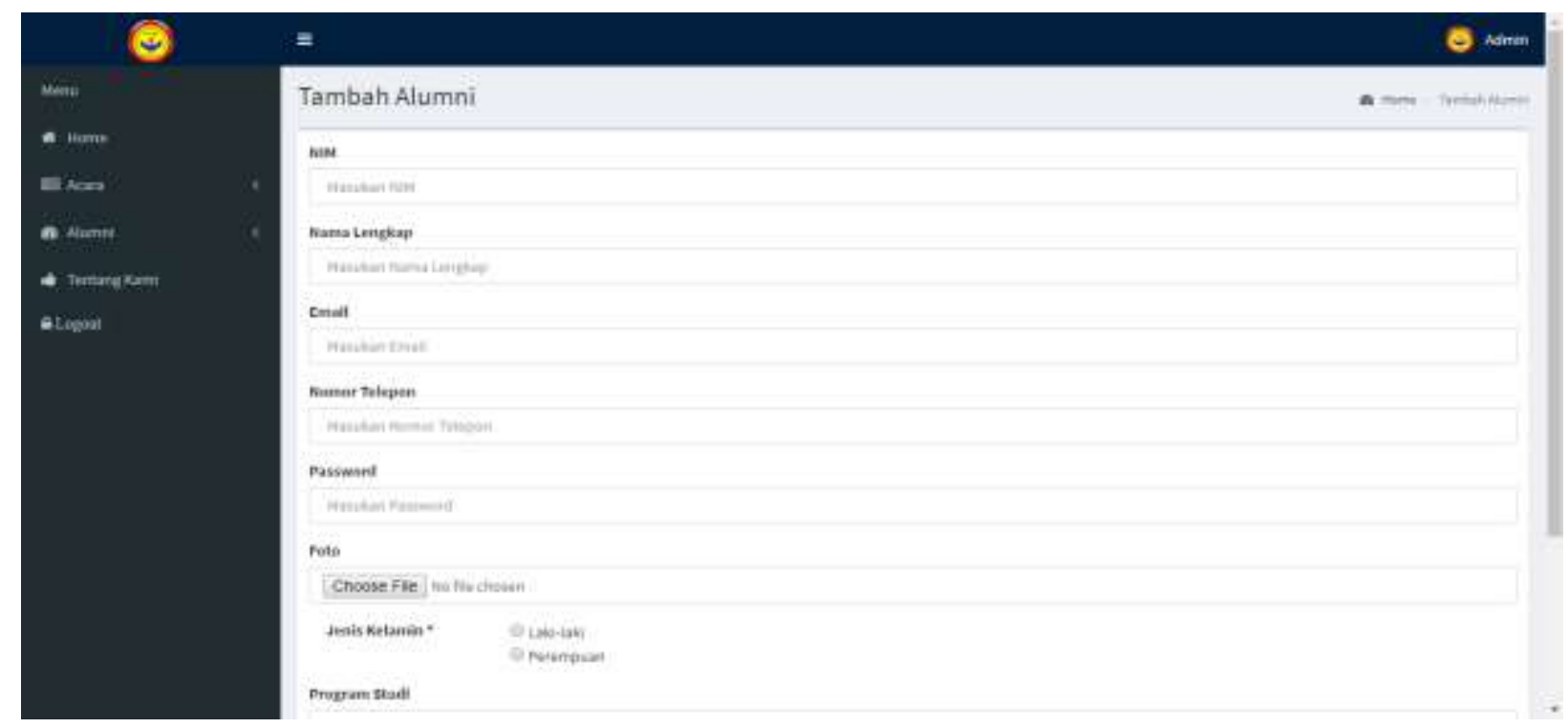

Figure 22. Display Add Graduates

Users (Admin / Study program) can add graduates were common and recorded in the data for university students as NIM, full name, and others. 


\section{Views Position Graduates}

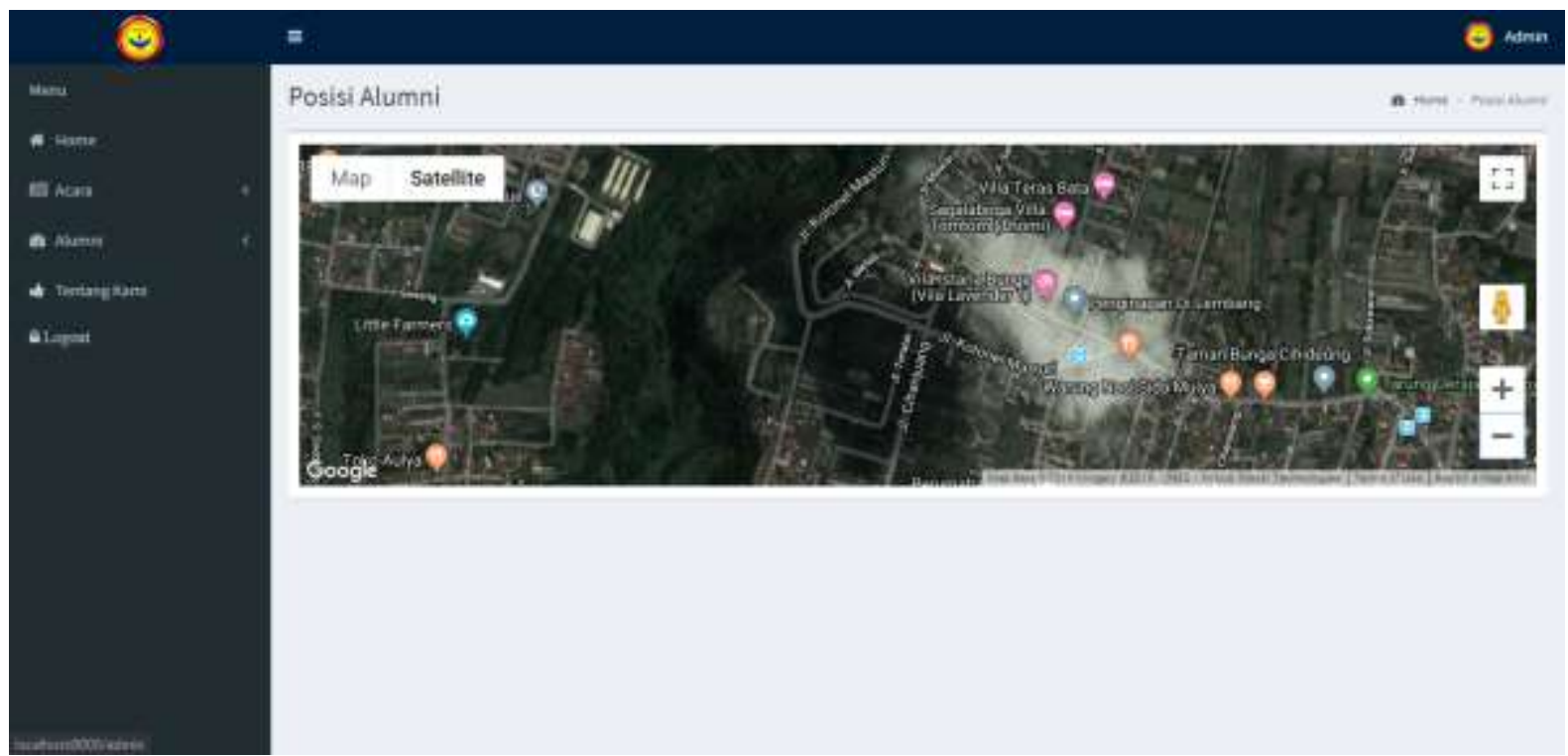

Figure 23. Position Display Graduates

User (Admin, Study program / rector) can see the position of graduate wherever he works through the marker position that was created by graduates in the data itself.

\section{Profile views Graduates}

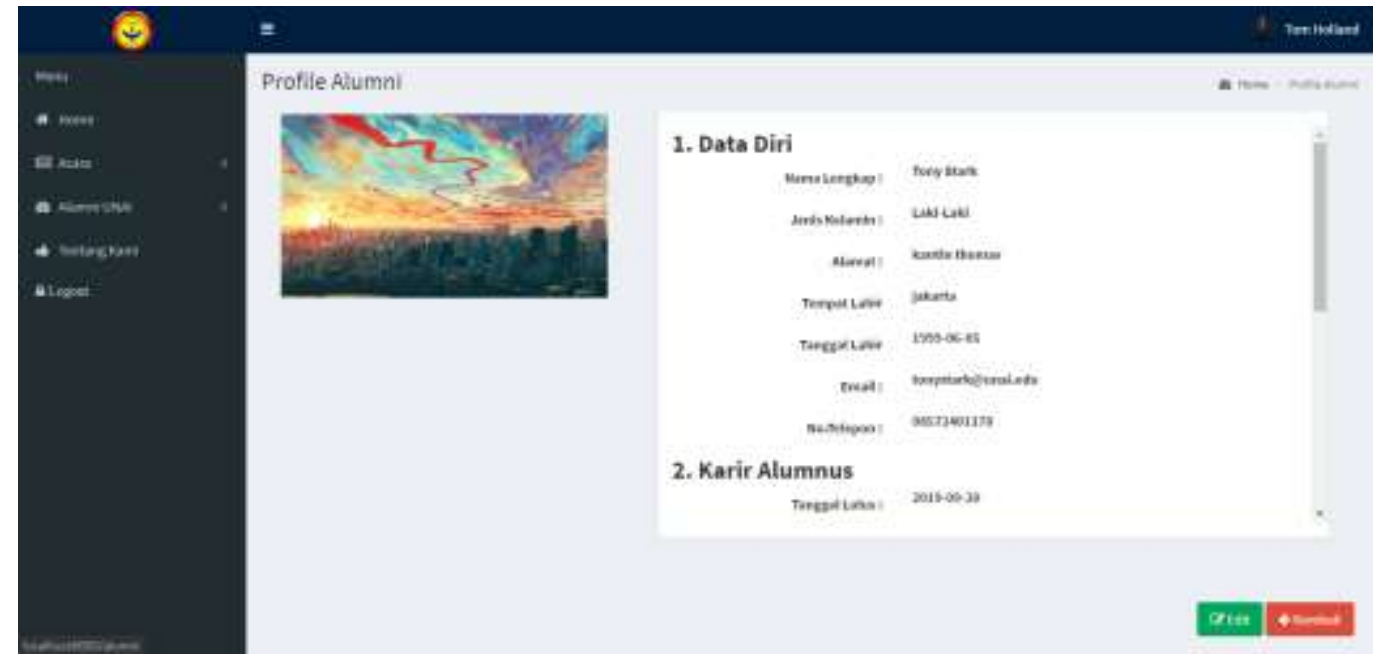

Figure 24. Display Profile Graduates

In profile view, graduates who already have login access can view and fill the specific personal data required by the college. 


\section{Display Edit Graduates}
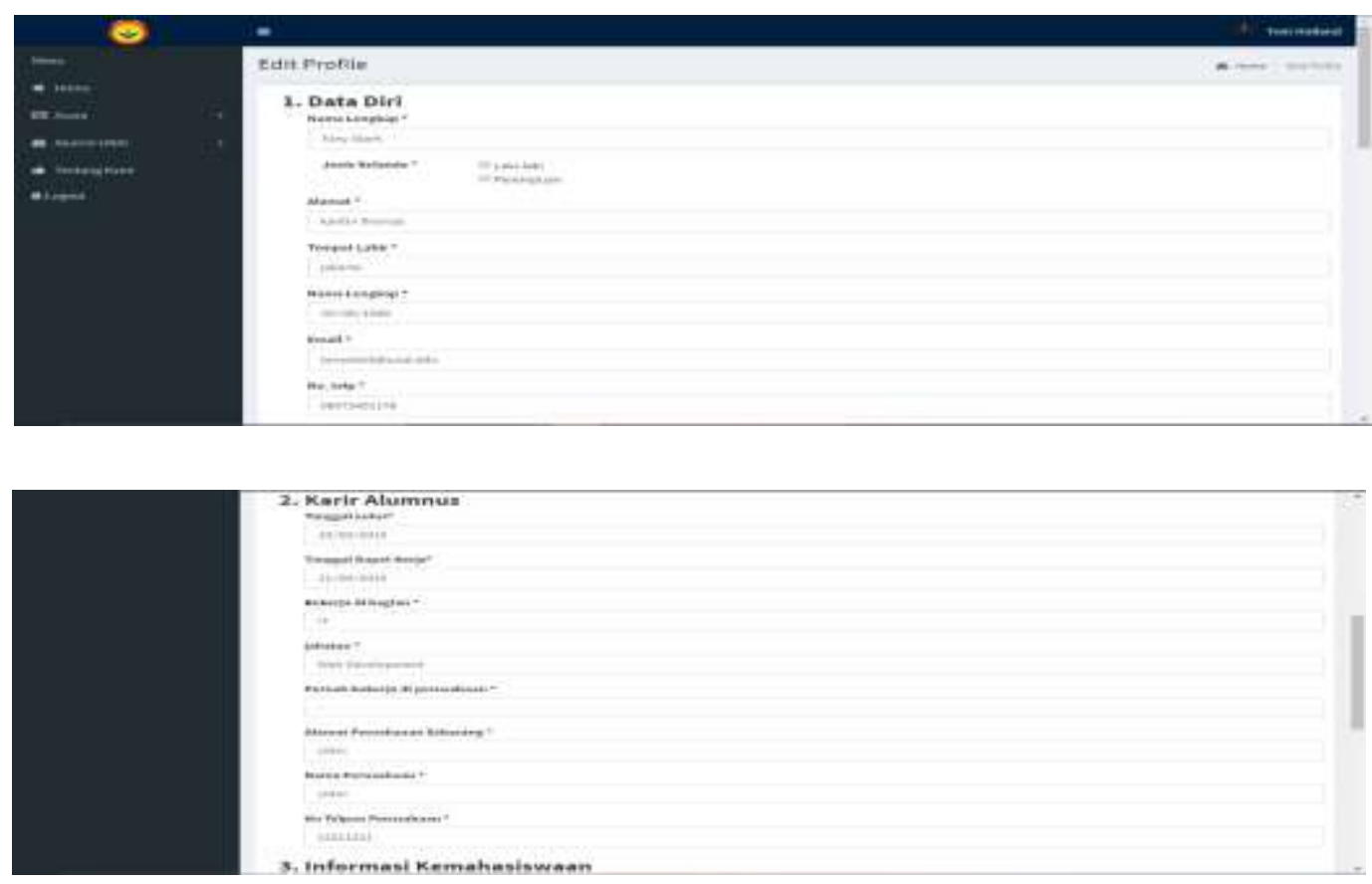

S. Informasi Kemahesiswan

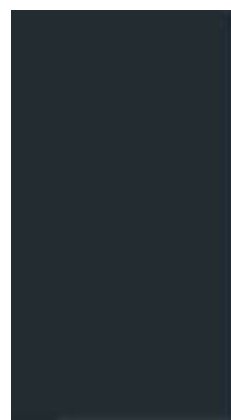

3. Enformasi Kamahasiswaen
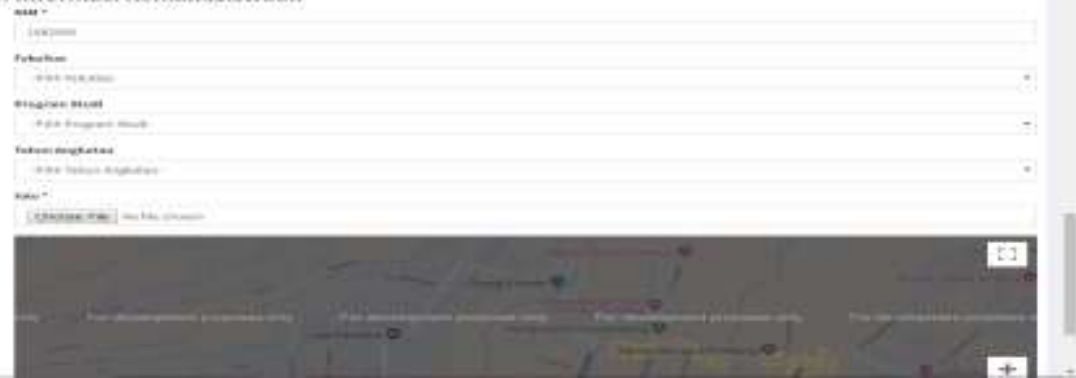

Figure 25. Display Data Edit Profile Graduates

After the user (Graduate) go to the profile page that they can edit their personal data and can

fill the data required by the university as part of a career.

\section{DISCUSSION}

The advice can be given for readers who want to develop a system tracer Universitas Advent Indonesia is getting better, namely:

1. The next expected, adding features scholarships.

2. Adding chart duration needed to get the job done.

3. Adding features job openings.

4. Integrating these applications as a means of finding access to graduate with official website (www.unai.edu)

\section{Conclusion}


Based on the research and design of applications that have been generated, it can be concluded that:

1. The study produced a web-based system tracer.

2. Can provide information about the data that can be seen passing graduates access the Web that have been made through the existing database.

3. This system can help a university to determine the time period required for graduates to get a job.

4. The system is running as expected writer

5. The system is capable of handling the data refineries, such as: (a) Management of the data indetitas graduates, (b) the data pengolalaan alumuni career, (c) management jobs data today from graduates.

6. The system can provide an overview to the university related to the absorption of graduates in the working world. 


\section{REFERENCES}

B, FS, Safi'ie, MA, \& WA, OD (2016). IMPLEMENTATION OF ACADEMIC INFORMA TION SYSTEM BASED WEB USING FRAMEWORK laravel. Journals TRANS FORMATION, 46-50.

Billy, RE, \& Sons, EK (2015). Information Systems Graduate School of Computer Science University of Klabat. National Conference on Systems and Informatics, 880-884.

Develop Faster with the laravel PHP, (2015, April 17). Taken back from developer.com

Effendy, DU, \& Suswanto, B. (t.thn.). MODEL-BASED DESIGN GRADUATE SURVEIL LANCE APPLICATIONS WEBSITE. DotCom Dynamics Journal Vol. 5 No. 1, 1426.

Khair, M., Astuti, IF, \& Khairina, DM (2016). Graduates Tracer Web-Based System (A Case Study of the Faculty of Mathematics and Natural Sciences). Proceedings of the Seminar on Science and Technology Faculty Unmul, 471-475.

Nasuha, A., \& Siahaan, K. (2016). ANALYSIS AND DESIGN OF INFORMATION SYST EMS GRADUATES (TRACER STUDY) WEB-BASED IN Sulthan Taha Saifuddin IAIN JAMBI. Journal of Management Information Systems Vol 1 No. 1, 18-29.

Pressman, R. (t.thn.). Software Engineering: Practitioner Approach Book I. Yogyakarta: Andi.

Purwati, N., Halimah, \& Rahardi, A. (2018). Website Designing Information System Studies Institute of Informatics and Business Darmajaya Bandar Lampung. Journal of Information Systems and Database Management (SIMADA), 71-80. 